\section{Box 1 Can biotech and organic farming co-exist?}

Co-existence-the idea that transgenic and non-GM crops of the same species can be successfully grown near each other-has for years been part of the European regulatory discussion. For instance, EU member states have imposed isolation distances on GM crop growers (Nat. Biotechnol. 28, 133-136, 2010). But it is only in the past 18 months or so that the concept has made headlines in the US with legal tussles at the state and federal level between the organic sector and seed companies or farmers growing biotech crops. In December, as a response to the fierce debate following the USDA's proposals for approving EPSPS transgenic alfalfa, USDA Secretary Tom Vilsack wrote an open letter urging co-existence among biotech, organic and conventional crop stakeholders, suggesting that the agency wants to "forge a new paradigm based on co-existence."

The clash between biotech crops and organic agriculture has "led to litigation and uncertainty. Such litigation will potentially lead to the courts deciding who gets to farm their way and who will be prevented from doing so.... Surely, there is a better way," Vilsack wrote. Three months ago, the agency proposed to place European-style isolation distances on EPSPS transgenic alfalfa. It later backed down from that proposal and instead announced in January it would implement nonregulatory measures to address co-existence. For instance, the agency plans to revive its advisory committee on biotech and 21 st century agriculture (AC21), which in 2008 produced a report on the issues surrounding coexistence. This time, the committee will be charged with guiding the agency on ways to strengthen co-existence.

But the agency's attempt to address the issue through federal regulations has met resistance from the biotech community.

"Farmers have always had disputes and farmers have always been able to work things out without getting a great deal of government involvement in the middle of it," says Alan McHughen, a plant biotechnologist at the University of California at Riverside. Left to the growers, disputes tend to get settled "with a compromise on both sides," he says.

\section{IN their words}

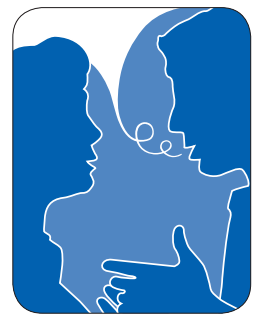

"In defense of the coffee and doughnuts, I would say there are probably some areas you can cut but I am not sure we should be inviting the most knowledgeable scientists in the world to talk about a cure for cancer and not offer them coffee." Democratic lawmaker

Chaka Fattah echoed calls to cut overblown budgets but drew the line at food. (AFP, 11 February 2011)

"What disturbs me a little is that a more-than-vivid imagination is needed to think that genealogy research in Iceland is being spied on if there is nothing behind it." Kari Stefánsson, executive chairman and president of research at deCODE, comments on last year's WikiLeaks disclosure that Chinese authorities may be spying on the company's genealogy and medical research database. (Iceland Review_Online, 6 December 2010)

"In recent years, big pharma, through a combination of internal research and acquisitions, has accumulated as much biotechnology capabilities as any biotech. What is left to differentiate big pharma from big biotech?" Columnist Jason Chew highlights the blurring line between pharma and biotech. (Seeking Alpha, 20 January 2011)

"It took us $\mathbf{3 0}$ years to get to where we are. So it will take some time to understand the next step, to understand the dynamics and the value." Genzyme CEO Henri Termeer comments on takeover talks between the biotech and Sanofi-aventis. (Boston Globe, 20 January 2011)

"You have to ask yourself why are physicians involved with these organizations at all? What's the benefit to society and medicine? In my mind, the answer is little or none." Jerome Kassirer, Tufts University Medical School professor and former editor-in-chief of the New England Journal of Medicine, supports a proposal from over a dozen medical journals to require authors of submissions to disclose payments from hedge funds or other investors. (Bloomberg, 19 January 2011)

"As a politician, I tend to listen to the emotions of the people. And yet as an engineer, I also have to listen to the scientific results." Emmanuel Pinol, vice governor of North Cotabato, Philippines, after the local government uprooted Bt eggplant field trials. (Crop Biotech Update, 14 January 2011).

"We need new tools. Nothing we've done in the past $\mathbf{4 0}$ years has had an impact." Duane Gubler, professor in infectious diseases at Singapore's DukeNUS Graduate Medical School, comments on the release of about 6,000 sterile Oxitec OX513A male mosquitoes into an uninhabited forest area in eastern Malaysia, part of a trial aimed at controlling dengue fever. (Associated Press, 26 January 2011).

\title{
Video games played with live organisms
}

'Biotic games' that mimic classic video games have been devised by Ingmar Riedel-Kruse and his team at Stanford. Single-celled organisms are placed in a microfluidics chamber with a microscope camera to track their movements. The image is overlaid on a game board. In PAC-mecium (pictured) the player guides paramecia up and down by changing the chamber's electrical field with a joystick. Paramecia gain points for gobbling yeast cells, and avoiding a computer-animated fish. There's Biotic Pinball, POND PONG and Ciliaball. Riedel-Kruse hopes these biotech games could become part of biology studies and contribute to crowd-sourcing and research. http://news.stanford.edu/news/2011/january/ biotic-video-games-011211.html

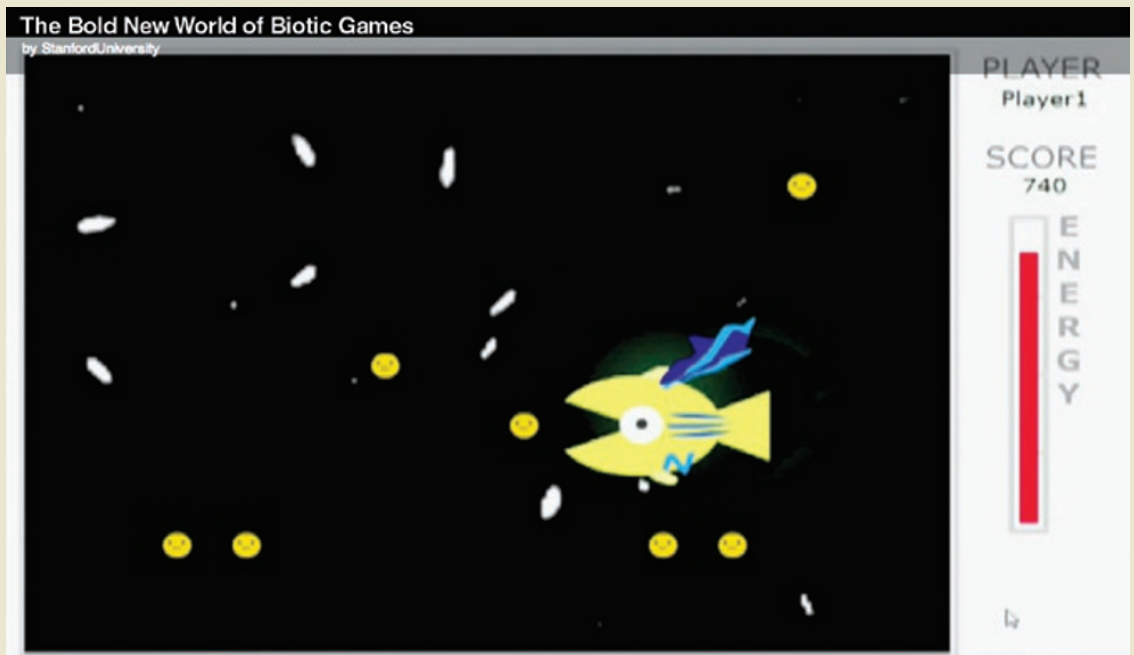

Tou IunejFiv 